\title{
Chemical Composition and Biological Properties of Essential Oils of Two Mint Species
}

\author{
Mei-Lin Tsai ${ }^{1}$, Chin-Tung Wu ${ }^{2}$, Tsen-Fang Lin ${ }^{1}$, Wei-Chao Lin ${ }^{1}$, Yu-Chun Huang ${ }^{3}$ \\ and Chao-Hsun Yang ${ }^{3 *}$ \\ ${ }^{1}$ Department of Cosmetic Science, Chia Nan University of Pharmacy and Science, Taiwan, 71710, ${ }^{2}$ Department of Computer \\ Science and Information Engineering, ${ }^{3}$ Department of Cosmetic Science, Providence University, Taichung 43301, Taiwan, ROC
}

*For correspondence: Email: chyang@pu.edu.tw, meilints@mail.chna.edu.tw; Tel: +886-4-26311167, +886-6-2664911.

Received: 14 May 2013

Revised accepted: 15 July 2013

\begin{abstract}
Purpose: To analyze the composition of essential oils of two types of mint as well as compare the antimicrobial, antioxidant and anti-inflammatory activities of the two oils.

Methods: Peppermint (M. piperita L.) and chocolate mint (M. piperita L.) oils were obtained by steam distillation in a Clevenger-type apparatus. The chemical composition of the essential oils was determined by gas chromatography-mass spectrometry (GC/MS). The minimal inhibitory concentration (MIC) of the essential oils were determined by broth dilution method. The antioxidant activities of the oils were determined by 2, 2-diphenyl-1-picrylhydrazyl (DPPH)DPPH radical scavenging assay, $\beta$-Carotene-linoleic acid assay, andnitric oxide (NO) radical scavenging assay.

Results: The two essential oils contain high levels of alcohol (43.47-50.10\%) and terpene (18.55-21.07\%) with the major compound being menthol (28.19-30.35\%). The antimicrobial activity (minimum inhibitory concentration, MIC) of peppermint oil against E. coli, S. aureus and $P$. aeruginosa $(0.15,0.08,0.92 \% \mathrm{v} / \mathrm{v}$, respectively) was stronger than that of chocolate mint $(0.23,0.09,1.22 \% \mathrm{v} / \mathrm{v}$, respectively). In the anti-oxidant test including $\mathrm{DPPH}$ and $\beta$-Carotenelinoleic acid assays, peppermint oil showed superior antioxidant properties to chocolate mint oil (4.45 - $19.86 \mu \mathrm{l} / \mathrm{mL})$. However, with regard to scavenging NO radical activity, chocolate mint oil exhibited higher activity than peppermint ( 0.31 and $0.42 \mu \mathrm{l} / \mathrm{mL}$, respectively). Chocolate mint oil also exhibited higher anti-inflammatory activity than peppermint oil $(0.03$ and $0.08 \mu \mathrm{l} / \mathrm{mL}$, respectively).

Conclusion: The results obtained should help to clarify the functional applications of these folk herbs and their essential oils for aromatherapeutic healing and other folkloric uses.
\end{abstract}

Keywords: Peppermint, Chocolate mint, Anti-microbial, Anti-oxidant, Anti-inflammatory

Tropical Journal of Pharmaceutical Research is indexed by Science Citation Index (SciSearch), Scopus, International Pharmaceutical Abstract, Chemical Abstracts, Embase, Index Copernicus, EBSCO, African Index Medicus, JournalSeek, Journal Citation Reports/Science Edition, Directory of Open Access Journals (DOAJ), African Journal Online, Bioline International, Open-J-Gate and Pharmacy Abstracts

\section{INTRODUCTION}

Essential oils are extracted from aromatic and medicinal plants that are natural concentrated aromatic hydrophobic liquid products obtained by steam distillation or solvent extraction [1,2]. They contain several chemical compounds exhibiting different biological properties and activities. It can reduce foodborne pathogens and decrease the use of synthetic and semisynthetic antimicrobial compounds [3].

Mints (Mentha spp.) are famous aromatic and medicinal herb that are used in traditional and folk medicines in the world for the antimicrobial and antioxidant properties. Mentha genus contains about 25 species and some hybrids and 
belongs to the Lamiaceae family [4]. Mints contain volatile components, flavonoids, organic acids, quinones, such as for the digestive system, central nervous system, respiratory system [5, 6]. It was used in antimicrobial, antiinflammatory or anesthesia [7]. M. piperita is a hybrid of spearmint (M. spicata L.) and water mint (M. aquatica L.), it grows particularly well in areas with high water-holding capacity soil [8].

In this study, we evaluated the major chemical compositions of the essential oils derived from the peppermint and chocolate mint by gas chromatography-mass spectrometry (GC-MS). We examined the antimicrobial activity of essential oils against some microorganisms. The antioxidant activities of the essential oils were determined by various antioxidant assays, including 2,2-diphenyl-1-picrylhydrazyl (DPPH) radical scavenging assay, $\beta$-Carotene/linoleic acid assay, and nitric oxide (NO) radical scavenging assay. Furthermore, the antiinflammatory activities of the essential oils were determined by 5-lipoxygenase (5-LOX) inhibition assay.

\section{EXPERIMENTAL}

\section{Plant material and isolation of essential oil.}

Peppermint (M. piperita L.) and chocolate mint (M. piperita L.) were purchased from a horticulture shop, Tangshan Herb Gardening, in Puli, Nantou County, Taiwan. The voucher specimens (peppermint no. CHNA MP 11001; chocolate mint no. CHNA MP 11002) were identified and deposited in the herbarium of the Department of Cosmetic Science, Chin Nan University of Pharmacy and Science, Tainan, Taiwan. The whole fresh plants were washed with distilled water (room temperature). The essential oils were obtained by steam distillation in a Clevenger-type apparatus. The essential oils collected were filtered through a $0.45 \mu \mathrm{m}$ filter and kept at $4{ }^{\circ} \mathrm{C}$ until further analysis. The steam distilled yields were about $0.3 \%$.

\section{Analysis of essential oil}

The essential oils were analyzed by GC/MS using a Hewlett-Packard GC systems (HP6890 series II) coupled with a mass detector (MSD5973) equipped with a HP-5MS capillary column (5\% phenyl methylsiloxane, $30 \mathrm{~m} \times 0.25$ $\mathrm{mm}$ id., $0.25 \mu \mathrm{m}$ film thickness) (Agilent Technologies, Palo Alto, CA). For GC/MS detection, an electron ionization system with ionization energy of $70 \mathrm{eV}$ was used over a scan range of 40-400 amu. Helium was used as a gas carrier at a flow rate of $1 \mathrm{~mL} / \mathrm{min}$. Split ratio was adjusted at 25:1. The column temperature was initially kept at $60{ }^{\circ} \mathrm{C}$ for $4 \mathrm{~min}$, then gradually increased up to $240{ }^{\circ} \mathrm{C}$ at an increment of 3 ${ }^{\circ} \mathrm{C} / \mathrm{min}$, and finally held isothermal for $10 \mathrm{~min}$. The percentage of components was calculated from total ion chromatograms. Identification of the primary component was assigned by matching mass spectral data with those detailed in Wiley 7n.1, and NIST02.L libraries [9].

\section{Bacterial strains and culture conditions}

The following were used as test bacteria: $E$. coli ATCC 2592, $S$. aureus ATCC 6538, $P$. aeruginosa ATCC 9027, P. ovale ATCC 12078, C. albicans ATCC 10231, and $P$. acnes ATCC 6919. All of the microorganisms were purchased from the Bioresource Collection and Research Center (BCRC, Hsinchu, Taiwan, ROC), and were employed in antimicrobial.

E. coli, $S$. aureus, and $P$. aeruginosa were incubated at $37{ }^{\circ} \mathrm{C}$ in TSB, and $P$. acnes was incubated anaerobically at $37{ }^{\circ} \mathrm{C}$ in RCM. $P$. ovale and $C$. albicans were cultured at $30{ }^{\circ} \mathrm{C}$ in Dixon medium (MEB with $2 \%$ ox-bile, $1 \%$ Tween-40, and $0.25 \%$ glycerol mono-oleate) and YMPD medium (0.3\% yeast extract, $0.3 \%$ malt extract, $0.5 \%$ peptone, and 1\% dextrose), respectively [10].

\section{Determination of antimicrobial activity}

The minimal inhibitory concentration (MIC) of the essential oils for the inhibition of six bacterial strains were determined by the broth dilution method with some modifications. Each test was executed in corresponding media supplemented with $0.5 \%$ Tween 80 . Serial dilutions of the essential oils were prepared in a 96-well microtiter plate over a range 0.02 to $49 \mathrm{mg} / \mathrm{mL}$. Overnight broth cultures of the various strains were prepared, and the final concentration in the various wells was adjusted to $2 \times 10^{4} \mathrm{CFU} / \mathrm{mL}$. Plates were incubated at the corresponding culture temperatures, with incubation time of $24 \mathrm{~h}$ for $E$. coli, $S$. aureus, $P$. aeruginosa, and $C$. albicans, $48 \mathrm{~h}$ for $P$. acnes, and $72 \mathrm{~h}$ for $P$. ovale. MIC was defined as the lowest concentration of the essential oil at which the microorganism does not exhibit visible growth, as indicated by the turbidity of the medium. MIC was defined as the lowest concentration of the essential oil at which inoculated microorganism was completely killed [9].

\section{Determination of antioxidant activity by DPPH radical scavenging assay}

Each concentration of essential oils was mixed 
individually into a methanolic solution containing DPPH radicals $(0.1 \mathrm{mM})$, and the final volume was $1 \mathrm{~mL}$. These solution mixtures were kept in dark for 30 minutes (incubation period) at room temperature. After thirty minutes, the absorbance was measured at $517 \mathrm{~nm}$ [11]. Each test was carried out in three times. Finally, DPPH radical scavenging activity (DPPH) was determined as in Eq 1.

$\operatorname{DPPH}(\%)=\left\{\left(A_{b}-A_{s}\right) / A_{b}\right\} 100$

where $A_{b}$ is the absorbance of blank and $A_{s}$ the absorbance of the sample.

\section{Determination of antioxidant activity by $\beta$ - Carotene-linoleic acid assay}

$\beta$-Carotene was dissolved in $0.2 \mathrm{~mL}$ of chloroform (1 $\mathrm{mg} / \mathrm{mL})$ and this was added to a solution of linoleic acid (20 mg) in $200 \mathrm{mg}$ of Tween 40. Chloroform was evaporated using a rotary evaporator under vacuum at $40^{\circ} \mathrm{C}$ for $5 \mathrm{~min}$. Distilled water $(50 \mathrm{~mL})$ was added to the flask and the mixture was stirred in a sonicator. Each concentration of essential oils was added individually to $4.8 \mathrm{~mL}$ of the emulsion and this was then incubated at $50^{\circ} \mathrm{C}$ for $3 \mathrm{~h}$. The absorbance was measured at $470 \mathrm{~nm}$ [9]. Reading of all samples were done immediately $(\mathrm{t}$ $=0 \mathrm{~h}$ ) and after $3 \mathrm{~h}$ of incubation. The antioxidant activities of the essential oils were evaluated in term of inhibition of $\beta$-Carotene (inhibition) as in Eq 2.

Inhibition $(\%)=\left\{\left(\mathrm{As}_{3 \mathrm{~h}}-\mathrm{Ab}{ }_{3 \mathrm{~h}}\right) /\left(\mathrm{Ab}_{0 \mathrm{~h}}-\right.\right.$
$\left.\left.\mathrm{A} \mathrm{b}_{3 \mathrm{~h}}\right)\right\} 100 \ldots \ldots \ldots \ldots \ldots \ldots \ldots \ldots \ldots \ldots \ldots \ldots \ldots \ldots \ldots \ldots \ldots \ldots \ldots \ldots \ldots \ldots \ldots \ldots \ldots$
$(2)$

where $\mathrm{As}_{3 \mathrm{~h}}$ is sample absorbance at the 3rd hour, $A b_{3 h}$ blank absorbance at the 3rd hour, $A b_{0 h}$ blank absorbance at $0 \mathrm{~h}$, and $A b_{3 h}$ blank absorbance at the 3rd hour

\section{Determination of antioxidant activity by NO radical scavenging}

Each concentration of essential oils was mixed individually with $0.1 \mathrm{~mL}$ of sodium nitroprusside (100 mM) and phosphate buffer solution $(\mathrm{pH}$ 7.4), yielding a final volume of $1 \mathrm{~mL}$. After $2.5 \mathrm{~h}$ of incubation at $20^{\circ} \mathrm{C}, 0.05 \mathrm{~mL}$ of the mixture was added to $0.05 \mathrm{~mL}$ of Griess reagent over $10 \mathrm{~min}$ at $25^{\circ} \mathrm{C}$. The absorbance was determined at 540 $\mathrm{nm}$ [12], and NO radical scavenging activity (NO) was obtained as in Eq 3

NO $(\%)=\left\{\left(A_{b}-A_{s}\right) / A_{b}\right\} 100$

where $A_{b}$ is the absorbance of blank and $A_{s}$ the absorbance of the sample.

\section{Determination of anti-inflammatory activity}

Linoleic acid was used as substrate for 5-LOX.
Various concentrations of $30 \mu \mathrm{L}$ aliquots of essential oil with $30 \mu \mathrm{L}$ of linoleic acid and potassium phosphate buffer (0.1 M, pH 6.3) containing 5-LOX (25 U), yielding a final volume of $3 \mathrm{~mL}$. The mixture was incubated at $25^{\circ} \mathrm{C}$ for $10 \mathrm{~min}$, and the absorbance was determind at $234 \mathrm{~nm}$ [13]. Because linoleic acid is enzymatically converted to a conjugated diene by 5 -LOX, which results in a continuous increase in absorbance at $234 \mathrm{~nm}$, inhibition activity (Infl) was calculated as in Eq 4.

$\operatorname{lnfl}(\%)=\left\{\left(A_{b}-A_{s}\right) / A_{b}\right\} 100$

where $A_{b}$ is the absorbance of blank and $A_{s}$ the absorbance of the sample.

\section{Statistical analysis}

All determinations were performed at least in triplicate. The results were analyzed by Student's $t$-test using Microsoft Excel 2007, and expressed as mean \pm standard deviation (SD) for each measurement. Differences were recognized as significant at $p<0.05$.

\section{RESULTS}

Based on GC/MS analysis, the major components of peppermint essential oil were menthol (30.35\%), menthone (21.12 \%), and trans-carane (10.99\%). In addition, we also found some other components of peppermint essential oil, including isomenthol, isopulegol, camphor. For the chocolate mint essential oil, the major components were menthol (28.19\%), menthone (15.53\%), 1,8-cineole (11.89\%), as shown in Table 1.

The essential oils of peppermint and chocolate mint have as their major compounds alcohols, terpenes and ketones. The essential oil of peppermint contained alcohols (43.47 \%), ketones $(25.9 \%)$, and terpenes (18.55\%) while the essential oil of chocolate mint contained alcohols $(50.1 \%)$, terpenes $(21.07 \%)$, and ketones $(9.68 \%)$, as Table 4 shows.

The results of the antioxidant assays of the two essential oils are stated in Table 3 . The $I_{50}$ value of peppermint essential oil were 4.45, 0.37 and $0.42 \mu \mathrm{l} / \mathrm{mL}$ for $\mathrm{DPPH}$ radical scavenging assay, $\beta$-Carotene-linoleic acid assay, and NO radical scavenging assay, respectively while the $\mathrm{IC}_{50}$ values of chocolate mint essential oil were $19.86,5.07$, and $0.31 \mu \mathrm{l} / \mathrm{mL}$, respectively. The antioxidant activities of peppermint essential oil were stronger than those of the essential oil of chocolate mint with regard to $\mathrm{DPPH}$ radical scavenging and $\beta$-Carotene-linoleic acid assays. 
Table 1: Major compounds (\%) of essential oils

\begin{tabular}{|c|c|c|c|c|}
\hline \multirow[b]{2}{*}{ S/No. } & \multicolumn{2}{|c|}{ Peppermint } & \multicolumn{2}{|l|}{ Chocolate mint } \\
\hline & Compound & Peppermint & Compound & $\begin{array}{c}\text { Chocolate } \\
\text { mint }\end{array}$ \\
\hline 1 & menthol & 30.35 & menthol & 28.19 \\
\hline 2 & menthone & 21.12 & menthone & 15.53 \\
\hline 3 & trans-carane & 10.99 & 1,8-cineole & 11.89 \\
\hline 4 & isomenthol & 6.26 & menthomenthene & 8.29 \\
\hline 5 & $(+)$-carvone & 5.60 & isomenthol & 7.08 \\
\hline 6 & 1,8-cineole & 5.33 & $(+)$-carvone & 5.33 \\
\hline 7 & mint furanone & 2.49 & $\begin{array}{c}\text { bicyclo[4.4.0]dec-1-ene, 2- } \\
\text { isopropyl-5-methyl-9-methylene- }\end{array}$ & 2.75 \\
\hline 8 & pulegone & 2.12 & D-(+)-camphor & 1.75 \\
\hline 9 & $\begin{array}{l}\text { mono-(2-ethyl } \\
\text { hexyl) ester }\end{array}$ & 0.85 & $\beta$-pinene & 1.37 \\
\hline 10 & menthyl acetate & 0.81 & mint furanone & 1.30 \\
\hline
\end{tabular}

Table 2: The minimal inhibitory concentration (MIC, \%v/v) of the essential oils.

\begin{tabular}{|c|c|c|c|c|c|c|c|}
\hline Essentail oil & & E. coli & S. aureus & P. aeruginos & P. ovale & P. acnes & C. albicans \\
\hline $\begin{array}{l}\text { Mentha } \\
\text { piperita L., } \\
\text { peppermint }\end{array}$ & $\mathrm{MIC}_{90}$ & $0.15 \pm 0.00$ & $0.08 \pm 0.00$ & $0.92 \pm 0.00$ & $0.22 \pm 0.00$ & $0.03 \pm 0.00$ & $0.08 \pm 0.00$ \\
\hline $\begin{array}{l}\text { Mentha } \\
\text { piperita L., } \\
\text { chocolate }\end{array}$ & $\mathrm{MIC}_{90}$ & $0.23 \pm 0.02$ & $0.09 \pm 0.00$ & $1.22 \pm 0.00$ & $0.21 \pm 0.00$ & $0.03 \pm 0.00$ & $0.09 \pm 0.00$ \\
\hline
\end{tabular}

Table 3: $I C_{50}(\mu \mathrm{l} / \mathrm{mL})$ values for antioxidant and anti-inflammatory activities of essential oils

\begin{tabular}{lcccc}
\hline & \multicolumn{3}{c}{ Antioxidant activity } & $\begin{array}{c}\text { Anti-inflammatory } \\
\text { activity }\end{array}$ \\
\cline { 2 - 5 } Essentail oil & $\begin{array}{c}\text { DPPH radical } \\
\text { scavenging } \\
\text { activity }\end{array}$ & $\begin{array}{c}\beta \text {-Carotene-linoleic } \\
\text { acid assay }\end{array}$ & $\begin{array}{c}\text { NO radical } \\
\text { scavenging } \\
\text { activity }\end{array}$ & 5-LOX inhibition assay \\
\hline $\begin{array}{l}\text { Mentha } \\
\text { piperita L., } \\
\text { peppermint }\end{array}$ & $4.45 \pm 0.75$ & $0.37 \pm 0.05$ & $0.42 \pm 0.01$ & $0.08 \pm 0.01$ \\
$\begin{array}{l}\text { Mentha } \\
\text { piperita L., } \\
\text { chocolate }\end{array}$ & $19.86 \pm 1.25$ & $5.07 \pm 0.17$ & $0.31 \pm 0.06$ & $0.03 \pm 0.01$ \\
\hline
\end{tabular}

Table 4: Classification of content of essential oil components (\%)

\begin{tabular}{ccc}
\hline $\begin{array}{c}\text { Class of } \\
\text { compund }\end{array}$ & Peppermint & Chocolate mint \\
\hline Alcohols & 43.47 & 50.10 \\
Ketones & 25.90 & 9.68 \\
Terpenes & 18.55 & 21.07 \\
Others & 9.27 & 15.90 \\
Esters & 2.81 & 3.25 \\
\hline
\end{tabular}

but lower with regard to NO radical scavenging assay. For anti-inflammatory activity.test, $\mathbf{I C}_{50}$ values were 0.08 and $0.03 \mu \mathrm{l} / \mathrm{mL}$ for essential oils of peppermint and chocolate mint, respectively (Table 3 ). The anti-inflammatory activity of chocolate mint essential oil was higher than that of peppermint essential oil.

MIC results (Table 2) show the essential oils of peppermint and chocolate mint exhibited the strongest bactericidal activity at a concentration 
of $0.03 \%(\mathrm{v} / \mathrm{v})$ against $P$. acnes. The MIC of peppermint essential oil decreased in the order: $P$. acnes $(0.03 \% \mathrm{v} / \mathrm{v})>S$. aureus $(0.08 \% \mathrm{v} / \mathrm{v})=$ C. albicans $>$ E. Coli $(0.15 \% \mathrm{v} / \mathrm{v})>P$. ovale $(0.22$ $\% \mathrm{v} / \mathrm{v})>P$. aeruginosa $(0.92 \% \mathrm{v} / \mathrm{v})$. The $\mathrm{MIC}$ of chocolate mint essential oil decreased in the order: $P$. acnes $(0.03 \% \mathrm{v} / \mathrm{v})>S$. aureus $(0.09 \%$ $\mathrm{v} / \mathrm{v})=C$. albicans $>P$. ovale $(0.21 \% \mathrm{v} / \mathrm{v})>E$. Coli $(0.23 \% \mathrm{v} / \mathrm{v})>P$. aeruginosa $(1.22 \% \mathrm{v} / \mathrm{v})$. The essential oil of peppermint demostrated stronger antimicrobial activity than that of chocolate mint.

\section{DISCUSSION}

The essential oils from peppermint and chocolate mint were analyzed to determine their chemical components. They were also tested for antimicrobial activity against Escherichia coli, Staphylococcus aureus, Pseudomonas aeruginosa, Pitrosporum ovale, Candida albicans, and Propionibacterium acnes. Besides, the essential oils were used in antioxidant, and anti-inflammatory assays.

Khan and Abourashed reported that peppermint yields $0.1-1.0 \%$ of volatile oil that is composed mainly of menthol (29-48\%), menthone (20 $31 \%)$, and menthyl acetate (3-10\%) [14]. This result is similar to ours. In our study, menthol and menthone were major compositions in both peppermint and chocolate mint essential oils. Menthyl acetate content was $0.81 \%$ in peppermint but was practically absent from chocolate mint.

The components of mint oils vary with plant maturity, variety, geographical region and processing conditions $[8,15,16]$.

Many studies have assessed the antibacterial [17] and antifungal [8] activities of peppermints. Our results showed that Gram-positive $S$. aureus and $P$. acnes were more sensitive to the essential oils than Gram-negative $E$. coli and $P$. aeruginosa. The results were similar to Djenane et al (2012) [18]. In previous studies, the mint essential oils had the ability to inhibit $P$. acnes [19]. Therefore, this property could be used for developing new anti-acne or antimicrobial ingredients from peppermint oils for cosmetic or personal products.

The antioxidant activity had different results by different assay systems [9]. The antioxidant activities of antioxidants have been attributed to various mechanisms, including the prevention of chain initiation, binding of transition metal ion catalysts, decomposition of peroxides, prevention of continued hydrogen abstraction, and radical scavenging [20].

\section{CONCLUSION}

This study showed the two mint essential oils contain more alcohol and terpene and the major compound was menthol. The antimicrobial activity of peppermint against $E$. coli, $S$. aureus and $P$. aeruginosa was stronger than that of chocolate mint. For the anti-oxidation test using DPPH radical and $\beta$-Carovtene-linoleic acid assay, peppermint showed better properties than chocolate mint. However, for the scavenging $\mathrm{NO}$ radical activity, chocolate mint was superior to peppermint. Chocolate mint also showed stronger anti-inflammatory activity than peppermint.

\section{REFERENCES}

1. Edris AE. Pharmaceutical and therapeutic potentials of essential oils and their individual volatile constituents: a review. Phytother Res 2007; 21: 308-323.

2. Dorman HJ, Deans SG. Antimicrobial agents from plants: antibacterial activity of plant volatile oils. $J$ Appl Microbiol 2000; 88: 308-316.

3. Liang R, Xu S, Shoemaker CF, Li Y, Zhong F, Huang Q. Physical and antimicrobial properties of peppermint oil nanoemulsions. J Agric Food Chem 2012; 60: 7548-7555.

4. Lopez V, Martin S, Gomez-Serranillos MP, Carretero ME, Jager AK, Calvo MI. Neuroprotective and neurochemical properties of mint extracts. Phytother Res 2010; 24: 869-874.

5. Stafford GI, Jager AK, van Staden J. Activity of traditional South African sedative and potentially CNS-acting plants in the GABA-benzodiazepine receptor assay. J Ethnopharmacol 2005; 100: 210215.

6. Lucchesi ME, Chemat F, Smadja J. Solvent-free microwave extraction of essential oil from aromatic herbs: comparison with conventional hydrodistillation. J Chromatogr A 2004; 1043: 323-327.

7. Hussain Al, Anwar F, Nigam PS, Ashraf M, Gilani AH. Seasonal variation in content, chemical composition and antimicrobial and cytotoxic activities of essential oils from four Mentha species. J Sci Food Agric 2010; 90: 1827-1836.

8. McKay DL, Blumberg JB. A review of the bioactivity and potential health benefits of peppermint tea (Mentha piperita L.). Phytother Res 2006; 20: 619-633.

9. Tsai ML, Lin CC, Lin WC, Yang CH. Antimicrobial, antioxidant, and anti-inflammatory activities of essential oils from five selected herbs. Biosci Biotechnol Biochem 2011; 75: 1977-1983.

10. Yu J, Lei J, Yu H, Cai X, Zou G. Chemical composition and antimicrobial activity of the essential oil of Scutellaria barbata. Phytochemistry 2004; 65: 881884.

11. Shimada K, Fujikawa K, Yahara K, Nakamura $T$. Antioxidative properties of xanthan on the autoxidation of soybean oil in cyclodextrin emulsion. J Agric Food Chem 1992; 40: 945-948.

12. Wadsworth TL, Koop DR. Effects of Ginkgo biloba extract (EGb 761) and quercetin on lipopolysaccharide-induced release of nitric oxide. Chem Biol Interact 2001; 137: 43-58.

13. Baylac $S$, Racine $P$. Inhibition of 5-lipoxygenase by 
essential oils and other natural fragrant extracts. Int $J$ Aromather 2003; 13: 138-142.

14. Khan IA, Abourashed EA. Leung's Encyclopedia of Common Natural Ingredients: Used in Food, Drugs and Cosmetics; 3rd ed.; John Wiley \& Sons, Inc. Hoboken, New Jersey, 2010.

15. Rohloff J, Dragland S, Mordal R, Iversen TH. Effect of harvest time and drying method on biomass production, essential oil yield, and quality of peppermint (Mentha $x$ piperita L.). J Agric Food Chem 2005; 53: 4143-4148.

16. Scavroni J, Boaro CSF, Marques MOM, Ferreira LC. Yield and composition of the essential oil of Mentha piperita L. (Lamiaceae) grown with biosolid. Braz. J. Plant Physiol. 2005; 17: 345-352.

17. Iscan G, Kirimer N, Kurkcuoglu M, Baser KH, Demirci F. Antimicrobial screening of Mentha piperita essential oils. J Agric Food Chem 2002; 50: 39433946.

18. Djenane $D$, Aider $M$, Yanguela J, Idir L, Gomez $D$, Roncales $P$. Antioxidant and antibacterial effects of Lavandula and Mentha essential oils in minced beef inoculated with E. coli O157:H7 and S. aureus during storage at abuse refrigeration temperature. Meat Sci 2012; 92: 667-674.

19. Zu Y, Yu H, Liang L, Fu Y, Efferth T, Liu $X, W u N$. Activities of ten essential oils towards Propionibacterium acnes and PC-3, A-549 and MCF-7 cancer cells. Molecules 2010; 15: 32003210.

20. Diplock AT. Will the 'good fairies' please prove to us that vitamin $E$ lessens human degenerative disease? Free Rad Res 1997; 27: 511-532. 